\title{
Prevalence of BRCA1 and BRCA2 Mutations in Patients with Primary Ovarian Cancer - Does the German Checklist for Detecting the Risk of Hereditary Breast and Ovarian Cancer Adequately Depict the Need for Consultation?
}

\section{Prävalenz von BRCA1- und BRCA2-Mutationen bei Patientinnen mit primärem Ovarialkarzinom - bildet die deutsche Checkliste zur Erfassung des Risikos für erblichen Brust- und Eierstockkrebs den Beratungsbedarf ausreichend ab?}

\section{(ㄷ) (1) (우) $\ominus$}

Authors

Beyhan Ataseven ${ }^{1,2}$, Denise Tripon ${ }^{1}$, Kerstin Rhiem ${ }^{3}$, Philipp Harter ${ }^{1}$, Stephanie Schneider ${ }^{1}$, Florian Heitz ${ }^{1,4}$, Thais Baert ${ }^{1,5}$, Alexander Traut ${ }^{1}$, Nina Pauly ${ }^{1}$, Sarah Ehmann ${ }^{1}$, Helmut Plett ${ }^{1,4}$, Rita K. Schmutzler ${ }^{3}$, Andreas du Bois ${ }^{1}$

Affiliations

1 Abteilung für Gynäkologie und Gynäkologische Onkologie, Evang. Kliniken Essen-Mitte, Essen

2 Klinik und Poliklinik für Frauenheilkunde und Geburtshilfe der LMU München, München

3 Zentrum Familiärer Brust- und Eierstockkrebs, Universitätsklinik Köln, Köln

4 Klinik für Gynäkologie mit Zentrum für onkologische Chirurgie (CVK) und Klinik für Gynäkologie (CBF), Charité - Universitätsmedizin Berlin, Berlin

5 Abteilung für Onkologie und Tumorimmunologie, KU Leuven, Leuven, Belgien

Key words

ovarian cancer, BRCA mutation, hereditary breast and ovarian cancer, heritability checklist

Schlüsselwörter

Ovarialkarzinom, BRCA-Mutation, hereditäres Mamma- und Ovarialkarzinom, Erblichkeits-Checkliste

received 1. 4.2020

accepted after revision

14.7. 2020

Bibliography

DOI https://doi.org/10.1055/a-1222-0042

Geburtsh Frauenheilk 2020; 80: 932-940 @ Georg Thieme

Verlag KG Stuttgart · New York | ISSN 0016-5751
Correspondence

PD Dr. med. Beyhan Ataseven

Abteilung für Gynäkologie und Gynäkologische Onkologie,

Kliniken Essen-Mitte

Henricistraße 92, 45136 Essen, Germany

b.ataseven@kem-med.com

Deutsche Version unter:

https://doi.org/10.1055/a-1222-0042

\section{ABSTRACT}

Background $B R C A 1 / 2$ mutations are the leading cause of hereditary epithelial ovarian cancer (EOC). The German Consortium for Hereditary Breast and Ovarian Cancer has defined inclusion criteria, which are retrievable as a checklist and facilitate genetic counselling/testing for affected persons with a mutation probability of $\geq 10 \%$. Our objective was to evaluate the prevalence of the $B R C A 1 / 2$ mutation(s) based on the checklist score (CLS).

Methods A retrospective data analysis was performed on EOC patients with a primary diagnosis treated between 1/ 2011-5/2019 at the Central Essen Clinics, where a BRCA1/2 genetic analysis result and a CLS was available. Out of 545 cases with a BRCA1/2 result (cohort A), 453 cases additionally had an extended gene panel result (cohort $B$ ).

Results A BRCA1/2 mutation was identified in $23.3 \%$ (127) 545 ) in cohort $A$, pathogenic mutations in non-BRCA1/2 genes were revealed in a further $6.2 \%$ in cohort $B$. In cohort $A, 23.3 \%$ $(127 / 545)$ of patients had a BRCA1 $(n=92)$ or BRCA2 $(n=35)$ mutation. Singular EOC (CLS 2) was present in $40.9 \%$. The prevalence for a $B R C A 1 / 2$ mutation in cohort $A$ was $10.8 \%$, $17.2 \%, 25.0 \%, 35.1 \%, 51.4 \%$ and $66.7 \%$ for patients with CLS 2, 3, 4, 5, 6 and $\geq 7$ respectively. The mutation prevalence 
in cohort B was $15.9 \%, 16.4 \%, 28.2 \%, 40.4 \%, 44.8 \%$ and $62.5 \%$ for patients with CLS 2, 3, 4, 5, 6 and $\geq 7$ respectively. Conclusions The BRCA1/2 mutation prevalence in EOC patients positively correlates with a rising checklist score. Already with singular EOC, the prevalence of a $B R C A 1 / 2$ mutation exceeds the required $10 \%$ threshold. Our data support the recommendation of the S3 guidelines Ovarian Cancer of offering genetic testing to all patients with EOC. Optimisation of the checklist with clear identification of the testing indication in this population should therefore be aimed for.

\section{ZUSAMMENFASSUNG}

Hintergrund $B R C A 1 / 2-M u t a t i o n e n$ sind die Hauptursache für erbliche epitheliale Ovarialkarzinome (EOC). Das Deutsche Konsortium für Familiären Brust- und Eierstockkrebs hat Einschlusskriterien definiert, welche als Checkliste abrufbar sind und Betroffenen mit einer Mutationswahrscheinlichkeit von $\geq 10 \%$ eine genetische Beratung/Testung ermöglichen. Unser Ziel war es, die Prävalenz der BRCA1/2-Mutation(en) auf Basis des Checklisten-Scores (CLS) zu evaluieren.

Methoden Es erfolgte eine retrospektive Datenanalyse von EOC-Patientinnen mit Primärdiagnose, die zwischen 1/20115/2019 an den Kliniken Essen-Mitte behandelt wurden und für die ein BRCA1/2-Genanalyse-Ergebnis und ein CLS vorlag.
Von 545 Fällen mit BRCA1/2-Ergebnis (Kohorte A) lag in 453 Fällen zusätzlich ein erweitertes Gen-Panel-Ergebnis (Kohorte B) vor.

Ergebnisse In 23,3\% (127/545) wurde in Kohorte A eine BRCA1/2-Mutation festgestellt, in Kohorte B zeigten sich bei weiteren 6,2\% pathogene Mutationen in Nicht-BRCA1/2-Genen. In Kohorte A hatten 23,3\% (127/545) der Patienten eine BRCA1- $(\mathrm{n}=92)$ oder BRCA2- $(\mathrm{n}=35)$ Mutation. Ein singuläres EOC (CLS 2) lag in 40,9\% vor. Die Prävalenz für eine BRCA1/2Mutation in Kohorte A betrug 10,8\%, 17,2\%, 25,0\%, 35,1\%, 51,4\% und 66,7\% für Patienten mit CLS 2, 3, 4, 5, 6 bzw. $\geq 7$. Die Mutationsprävalenz in Kohorte B betrug 15,9\%, 16,4\%, $28,2 \%, 40,4 \%, 44,8 \%$ und 62,5\% für Patienten mit CLS 2, 3 , 4, 5, 6 bzw. $\geq 7$.

Schlussfolgerungen Die BRCA1/2-Mutationsprävalenz bei EOC-Patienten korreliert positiv mit steigendem ChecklistenScore. Bereits beim singulärem EOC überschreitet die Prävalenz einer BRCA1/2-Mutation die geforderte 10\%-Schwelle. Unsere Daten unterstützen die Empfehlung der S3-Leitlinie Ovarialkarzinom, allen Patientinnen mit EOC eine genetische Testung anzubieten. Eine Optimierung der Checkliste mit eindeutiger Kennzeichnung der Testungsindikation in dieser Population ist daher anzustreben.

\section{Introduction}

With 7350 new cases, ovarian cancer is the third most common gynaecological malignancy in Germany after breast and endometrial cancer [1]. Over $90 \%$ of these cases are tumours of epithelial origin - grouping together epithelial ovarian, fallopian tube and peritoneal cancer. Although the lifetime risk of developing ovarian cancer in the general population is rather low at around 1.5\% [2], this risk of disease increases manifold if a pathogenic gene mutation is present, as, for example - in the case of a BRCA1 mutation to $40-63 \%$, or - in the case of a BRCA2 mutation - to $16-27 \%$ [3$7]$. The prevalence of a $B R C A 1 / 2$ mutation in the normal population is estimated to be $1: 300-500$ [8-13]. The prevalence is however clearly above $10 \%$ in persons where there is familial clustering of breast and ovarian cancers. In Germany, the indication for genetic germline testing for pathogenic mutations is indicated according to the criteria of the German Consortium for Hereditary Breast and Ovarian Cancer [14]. The genetic counselling and testing can be conducted by authorised persons (human geneticists and physicians with the appropriate additional qualification) within and outside of the German Consortium for Hereditary Breast and Ovarian Cancer. In addition, (following clarification of cost assumption by the cost-bearer), genetic counselling and testing can be conducted outside of these indications in justified cases (e.g. mutation probability $\geq 10 \%$ in women with triple negative breast cancer or singular ovarian cancer). The test criteria are based on considerations of capacity of supply and on costs, which, in the past, have led to in many countries a mutation prevalence requirement of at least $10 \%$ as inclusion criterion for being offered genetic testing. Nevertheless, country-specific differences exist such as in the USA with the recommendations of the NCCN (National Comprehensive Cancer Network). Here the criteria are much broader and include the recommendation for conducting genetic counselling and testing already in all persons with a mutation probability of $5 \%$. This includes, for example, women with singular EOC regardless of family history, but also patients with prostate cancer, pancreatic cancer, and triple negative breast cancer up to 60 years of age [15]. With the introduction of high-throughput methods, which enable faster and more efficient genetic analysis, these boundaries are to be challenged in the future. Technological progress also enables genetic analyses to be extended to additional genes, which, if mutated, signify a marked increase in the lifetime risk of developing breast and/or ovarian cancer. Multigene panel analyses have already been in use and increasing in popularity in routine diagnostics for several years. At the same time, it is worth considering that the disease penetrances are also lower in patient cohorts with a low mutation prevalence.

Kast et al. [12] evaluated the prevalence of a pathogenic BRCA1/2 mutation based on the personal and family history of breast and/or ovarian cancer patients and were able to successfully define criteria for the clear identification of the at-risk population in Germany, assuming a mutation probability of $\geq 10 \%$. For easy application, these were implemented in a user-friendly checklist [16], which records the personal and family history of healthy people seeking advice and those who have become ill, based on a three-generation family tree. Risk scores are assigned depending on the number and type of tumours in the family, but also on the individual age of initial manifestation of the disease. With a checklist score (CLS) of $\geq 3$, a mutation probability of $\geq 10 \%$ is assumed, and affected persons are therefore offered ge- 


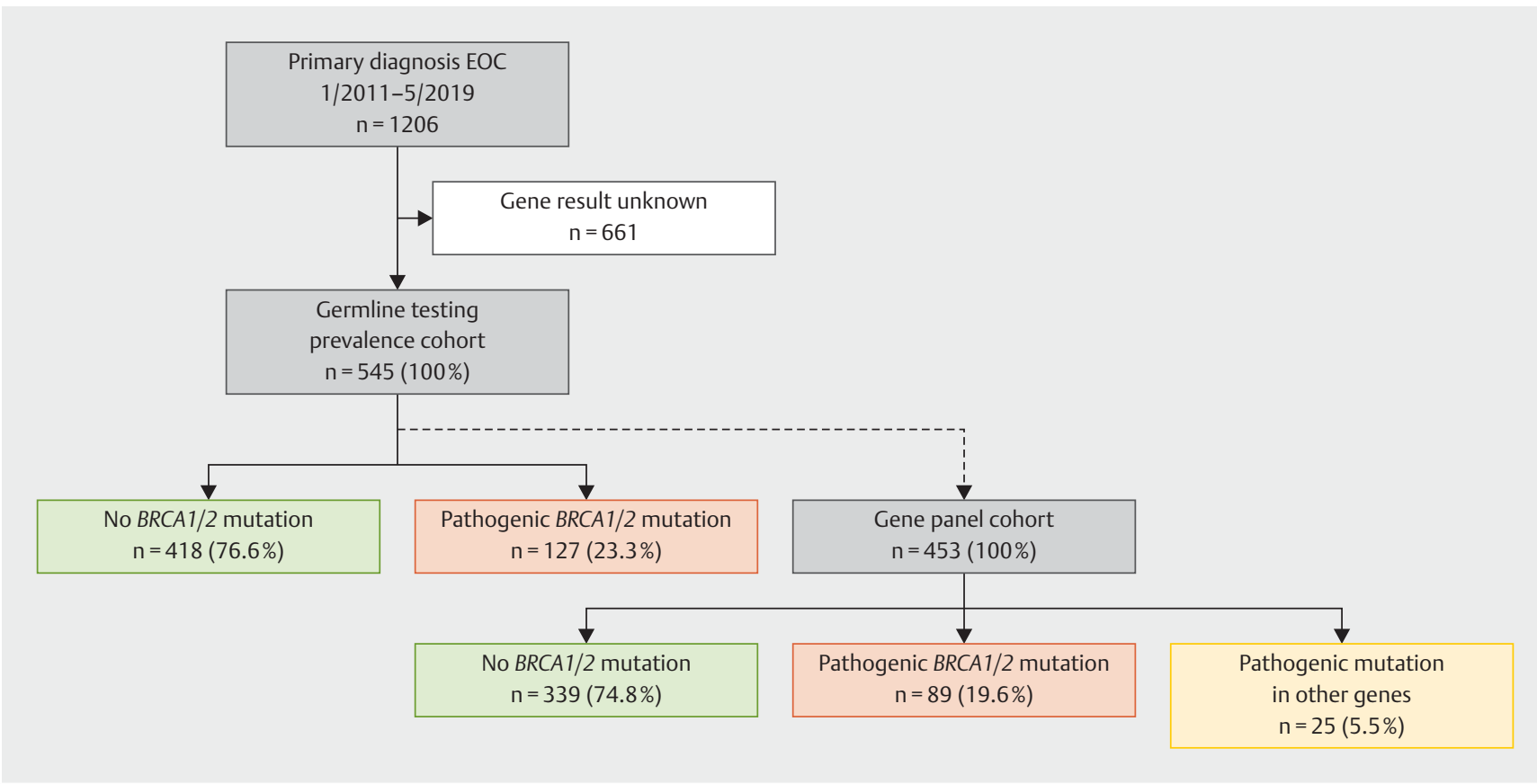

Fig. 1 Consort diagram.

netic counselling and testing covered by the cost bearers. The user-friendly form of the checklist led to successful implementation in everyday clinical practice. The positive correlation of the checklist with a BRCA1/2 mutation could already be demonstrated in breast cancer patients [17]. In addition, recording of a hereditary predisposition based on this checklist is required as a quality criterion in the certification requirements of the German Cancer Society (DKG; $[18,19])$.

An aspect of criticism concerning the checklist, however, is that ovarian cancer patients with no other familial breast/ovarian cancer history (so-called "singular ovarian cancer") achieve a score (CLS) of 2 points and therefore do not receive an offer of genetic counselling and subsequent testing. Within the scope of the AGO-TR1 study [20], it was possible to show for the first time for Germany, in a large collective of EOC patients, that the prevalence for a pathogenic BRCA1/2 mutation is above the required $10 \%$ threshold even in women with singular ovarian cancer. Thanks to these study data, an expansion of the inclusion criteria of the German Consortium for Hereditary Breast and Ovarian Cancer has been achieved since 2016, although not across all health insurers, with the result that a genetic test is now also possible for women with singular ovarian cancer within the framework of special contracts with the Consortium centres. The current S3 guideline on malignant ovarian cancers [21] recommends briefing patients with ovarian cancer (regardless of family history and age of disease onset) about the risk of a hereditary disease and offering genetic testing (recommendation grade $\mathrm{A}$, evidence level 2+).

Knowledge of the BRCA status in EOC patients is essential, among other things, for personalisation/optimisation of systematic therapy, but also for identification of family members who carry a relevant mutation and thus have a significantly higher risk of developing breast and/or ovarian cancer.

The objective of our work was to record the prevalence of a pathogenic BRCA1/2 mutation in unselected patients with epithelial ovarian cancer and to correlate this with the heritability checklist of the German Consortium for Hereditary Breast and Ovarian Cancer.

\section{Patients and Methods}

All patients with epithelial ovarian/fallopian tube/peritoneal cancer, who were treated between January 2011 and May 2019 in the Department for Gynaecology and Gynaecological Oncology of the Central Essen Clinics, were enrolled in this retrospective survey. Only patients who gave their written consent to the collection, processing and analysis of clinical data and the results of the genetic analyses were included in the evaluation. For the majority of patients, the indication for genetic counselling and testing was based on the inclusion criteria of the German Consortium for Hereditary Breast and Ovarian Cancer. Patients who had received genetic testing in the course of ongoing clinical studies were included, provided that the patient's consent to the use of this data had been provided. The genetic analyses were carried out in accordance with the provisions of the German Genetic Diagnostics Act after extensive counselling and written consent of the affected persons within the scope of the cooperation agreement with the German Consortium for Hereditary Breast and Ovarian Cancer. Alternatively, where the analyses were carried out via other/external institutions, they were submitted to us for information by the patients themselves. The results of the analyses and the final human genetic categorisation were collected from the written 
reports. Patients who had received a genetic analysis within the German Consortium from 2015 onwards, were analysed with the TruRisk $^{\circledR}$ gene panel, which contains other core genes (including ATM, BRIP1, CDH1, CHEK2, MLH1, MSH2, MSH6, PMS2, PALB2, RAD51C, RAD51D, TP53) in addition to the BRCA1/2 genes [22].

Recording of the checklist score took place within the scope of the genetic counselling on the basis of the individual patient medical history and family history. The principle of the checklist is based on the following: The purpose of the checklist is to identify patients and those seeking advice who could have a potential hereditary predisposition for breast and/or ovarian cancer. For this purpose, the checklist asks information about the patient, his/ her children and siblings (A) as well as about other patients on the maternal side including the mother (B) and/or on the paternal side including the father $(C)$, and rates this information with a corresponding point value. The highest total value (D) is obtained from the maternal/paternal line. The final checklist score is calculated from the sum of A and D. The model is based on a mathematical weighting, which has evaluated mutation prevalences in corresponding family/disease constellations through previous studies [12]. With a total checklist value is $\geq 3$ (E), the person concerned is recommended genetic counselling and testing.

For comparisons of frequencies, the $x^{2}$ and Fisher test (categorical variables) or T test (normally distributed/interval-scaled variables) were used, depending on variable category. A p-value $<0.05$ was considered significant. The statistical evaluations were carried out with SPSS version 23.0 (IBM Corporation, New York, USA) software.

\section{Results}

\section{Patients and cancer characteristics}

In the aforementioned time period, 1206 patients with epithelial ovarian cancer were treated. $45.2 \%$ (prevalence cohort, $n=545$ ) of the patients had an evaluable BRCA1/2 gene result coupled with recording of a checklist score ( $\bullet$ Fig. $\mathbf{1})$. In a comparison of the prevalence cohort with patients who were not entered in this analysis $(n=661)$ significant differences were revealed in the ECOG Performance Status (94.9\% versus $89.3 \%, p<0.001)$, in FIGO stage (Fédération Internationale de Gynécologie et d'Obstétrique; FIGO III/IV: 84.8 versus $80.2 \%$ ) and in the histology (highgrade serous EOC: 79.8 versus $74.1 \%$ ). There was no difference between either group in median age and personal history of previous malignancies.

The median age in the prevalence cohort was 58 years (range $18-86)$, the disease was at FIGO stage III/IV in $84.8 \%(n=462)$ and a high-grade serous histological subtype was present in $79.8 \%$ ( $\triangleright$ Table 1 ). $84.4 \%$ of patients $(n=460)$ had no previous malignant disease in their personal medical history, breast cancer was documented in $8.8 \%(n=48)$ and another malignancy in $6.8 \%$ $(n=37)$. A pathogenic BRCA1/2 mutation was identified in $23.3 \%$ $(\mathrm{n}=127)$ of patients. This was based on a BRCA1 mutation in $16.9 \%(n=92)$ and on a BRCA2 mutation in $6.4 \%(n=35)$ of cases. One patient had a simultaneous pathogenic BRCA1 and BRCA2 mutation. Patients with a $B R C A 1 / 2$ mutation differed significantly from those patients without a mutation in terms of median age
- Table 1 Patient characteristics.

\begin{tabular}{|c|c|c|c|c|}
\hline & Total & $\begin{array}{l}\text { No } \\
\text { BRCA1/2 } \\
\text { mutation }\end{array}$ & $\begin{array}{l}\text { Patho- } \\
\text { genic } \\
\text { BRCA1/2 } \\
\text { mutation }\end{array}$ & p-value \\
\hline & $\mathbf{N} / \%$ & $\mathbf{N} / \%$ & $\mathrm{~N} / \%$ & \\
\hline $\mathrm{N}$ & 545 & 418 & 127 & \\
\hline $\begin{array}{l}\text { Age - median } \\
\text { (range) }\end{array}$ & $\begin{array}{l}58 \\
(18-86)\end{array}$ & $\begin{array}{l}59 \\
(18-86)\end{array}$ & $\begin{array}{l}55 \\
(21-76)\end{array}$ & 0.010 \\
\hline $\begin{array}{l}\text { ECOG Per- } \\
\text { formance Status }\end{array}$ & & & & 0.106 \\
\hline .0 & 517 (94.9) & $393(94.0)$ & $124(97.6)$ & \\
\hline.$>0$ & $28(5.1)$ & $25(6.0)$ & $3(2.4)$ & \\
\hline $\begin{array}{l}\text { Personal history } \\
\text { of past } \\
\text { malignancies }\end{array}$ & & & & 0.095 \\
\hline - None & $460(84.4)$ & $354(84.7)$ & $106(83.5)$ & \\
\hline - Breast cancer & $48(8.8)$ & $32(7.7)$ & $16(12.6)$ & \\
\hline $\begin{array}{l}\text { - Other } \\
\text { malignancies }\end{array}$ & $37(6.8)$ & $32(7.7)$ & $5(3.9)$ & \\
\hline FIGO stage & & & & 0.033 \\
\hline - FIGOI & $50(9.2)$ & $46(11.0)$ & $4(3.1)$ & \\
\hline - FIGO II & $33(6.1)$ & $27(6.5)$ & $6(4.7)$ & \\
\hline - FIGO III & $207(38.0)$ & $151(36.1)$ & $56(44.1)$ & \\
\hline - FIGOIV & $255(46.8)$ & $194(46.4)$ & $61(48.0)$ & \\
\hline Histology & & & & $<0.001$ \\
\hline $\begin{array}{l}\text { - High-grade } \\
\text { serous }\end{array}$ & 435 (79.8) & $310(74.2)$ & $125(98.4)$ & \\
\hline $\begin{array}{l}\text { - Low-grade } \\
\text { serous }\end{array}$ & $33(6.1)$ & $33(7.9)$ & 0 & \\
\hline - Clear cell & $23(4.2)$ & $23(5.5)$ & 0 & \\
\hline $\begin{array}{l}\text { - High-grade } \\
\text { endometrioid }\end{array}$ & $17(3.1)$ & $16(3.8)$ & $1(0.8)$ & \\
\hline $\begin{array}{l}\text { - Low-grade } \\
\text { endometrioid }\end{array}$ & $12(2.2)$ & $12(2.9)$ & 0 & \\
\hline - Mucinous & $16(2.9)$ & $16(3.8)$ & 0 & \\
\hline $\begin{array}{l}\text { - Carcino- } \\
\text { sarcoma }\end{array}$ & $1(0.2)$ & 0 & $1(0.8)$ & \\
\hline - Other & $8(1.5)$ & $8(1.9)$ & 0 & \\
\hline
\end{tabular}

( 55 versus 59 years, $p=0.01$ ), FIGO stage (FIGO III/IV: 92.2 versus $82.5 \%, p=0.03$ ) and histological sub-type (high-grade serous: 98.4 versus $74.2 \%, p \leq 0.001)$ ( $>$ Table 1 ).

\section{Heritability checklist}

The distribution of the checklist score (CLS) in the prevalence cohort $(n=545)$ was as follows: CLS 2 in 40.9\% $(n=223)$, CLS 3 in $16.0 \%(n=87)$, CLS 4 in $19.8 \%(n=108)$, CLS 5 in $10.5 \%(n=57)$, CLS 6 in $6.8 \%(n=37)$ and CLS $\geq 7$ in $6.1 \%(n=33)$ ( $\triangleright$ Table 2$)$. The prevalence $(\%$, [95\% confidence interval $\{\mathrm{Cl}\}])$ for a pathogenic BRCA1/2 mutation based on the CLS point value of $2,3,4,5,6$, and $\geq 7$ was $10.8 \%$ (95\% Cl $7.0-15.6 \%), 17.2 \%$ (95\% Cl $10.0-$ 


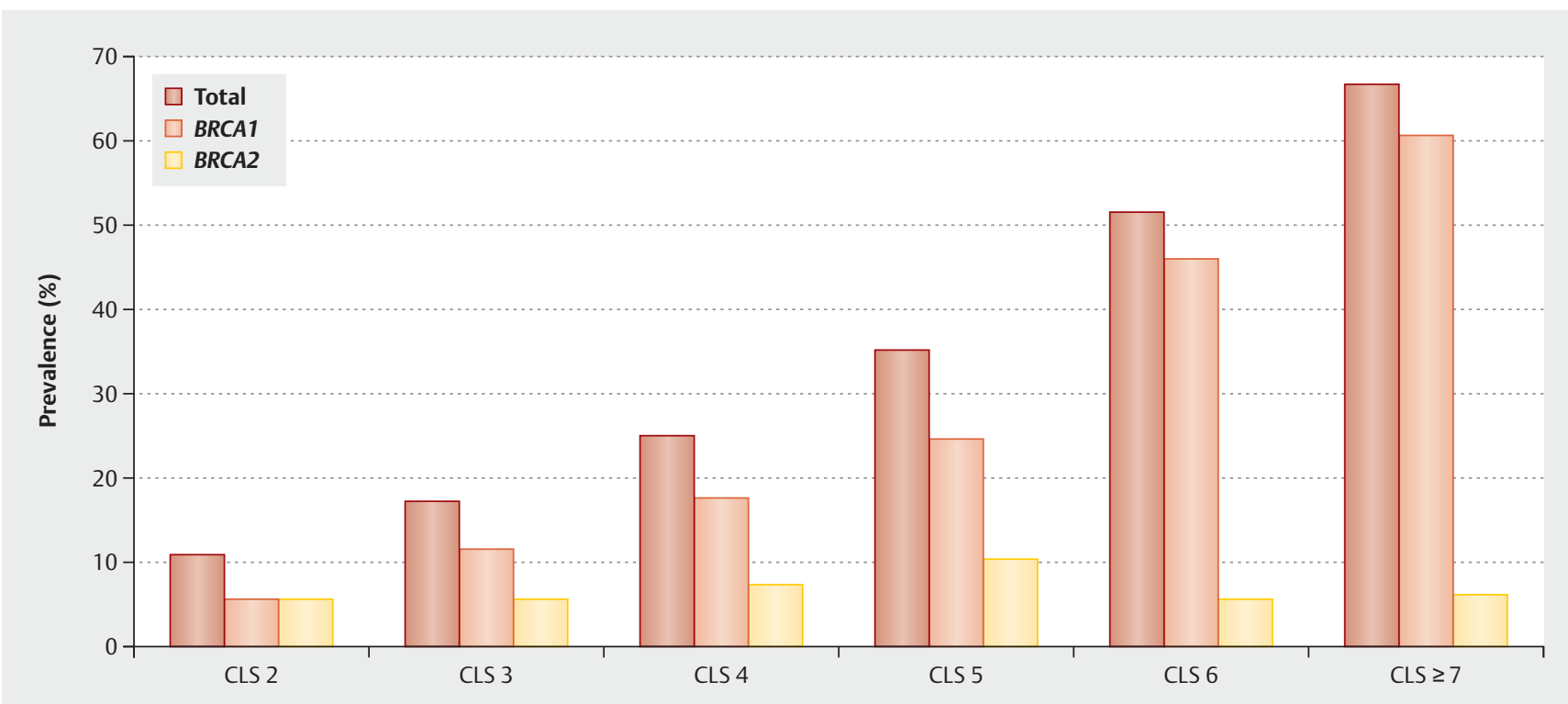

- Fig. 2 Prevalence of a pathogenic BRCA1/2 mutation depending on the heritability checklist score (CLS) in the overall cohort ( $n=545)$.

- Table 2 Distribution of patients depending on the heritability checklist score and detection of a BRCA1/2 mutation.

\begin{tabular}{|c|c|c|c|c|c|}
\hline $\begin{array}{l}\text { Checklist } \\
\text { score }\end{array}$ & Total & $\begin{array}{l}\text { No BRCA1/2 } \\
\text { mutation }\end{array}$ & $\begin{array}{l}\text { Pathogenic BRCA1/2 } \\
\text { mutation }\end{array}$ & $\begin{array}{l}\text { Pathogenic BRCA1 } \\
\text { mutation }\end{array}$ & $\begin{array}{l}\text { Pathogenic BRCA2 } \\
\text { mutation }\end{array}$ \\
\hline 2 & $223(40.9)$ & $199(47.6)$ & $24(18.9)$ & $12(13.0)$ & $12(34.3)$ \\
\hline 3 & $87(16.0)$ & $72(17.2)$ & $15(11.8)$ & $10(10.9)$ & $5(14.3)$ \\
\hline 4 & $108(19.8)$ & $81(19.4)$ & $27(21.3)$ & $19(20.7)$ & $8(22.9)$ \\
\hline 5 & $57(10.5)$ & $37(8.9)$ & $20(15.7)$ & $14(15.2)$ & $6(17.1)$ \\
\hline 6 & $37(6.8)$ & $18(4.3)$ & $19(15.0)$ & $17(18.5)$ & $2(5.7)$ \\
\hline$\geq 7$ & $33(6.1)$ & $11(2.6)$ & $22(17.3)$ & $20(21.7)$ & $2(5.7)$ \\
\hline
\end{tabular}

$26.8 \%$ ), $25.0 \%$ (95\% Cl 17.2-34.2\%), 35.1\% (95\% Cl 22.9-48.9\%), $51.4 \%(95 \% \mathrm{Cl} 34.4-68.1 \%)$ and $66.7 \%$ (95\% Cl 48.2-82.0\%) ( $\triangleright$ Table 2, Fig. 2).

\section{Gene panel analysis}

The result of a gene panel analysis was available for 453 patients (83.1\%). The rate of pathogenic BRCA1/2 mutations in this collective was $19.6 \%(n=89)$ ( $\triangleright$ Fig. 1). Furthermore, in 25 patients (5.5\%) additional pathogenic mutations were detected in genes RAD51C ( $\mathrm{n}=7)$, BRIP1 $(\mathrm{n}=4)$, MSH6 $(\mathrm{n}=3)$, PALB2 $(\mathrm{n}=3)$, RAD51D $(\mathrm{n}=2)$, TP53 $(\mathrm{n}=2)$, CHEK2 $(\mathrm{n}=2)$, PMS2 $(\mathrm{n}=1)$ and ATM $(\mathrm{n}=1)$. In total, the prevalence for a pathogenic gene mutation was $15.9 \%$ for CLS 2, $16.4 \%$ for CLS 3, $28.2 \%$ for CLS $4,40.4 \%$ for CLS 5 , $44.8 \%$ for CLS 6 and $62.5 \%$ for CLS $\geq 7$. If the prevalence of pathogenic mutations is considered depending on the checklist score value, there is still a clear correlation between the score value and the presence of a BRCA1/2 mutation (10-63\%), which, however, cannot be detected in patients with non-BRCA mutations ( $\triangleright$ Fig. 3).

\section{Discussion}

A pathogenic BRCA1/2 mutation is present in around $15-22 \%$ of all ovarian cancer patients [20,23-25]. In our survey, the rate of $B R C A 1 / 2$ mutations was $23 \%$. Accurate recording of BRCA status has in the meantime two important implications for women with ovarian cancer: on the one hand, the optimisation and individualisation of systematic therapy for patients with BRCA mutation (e.g. PARP-[Poly-ADP-Ribose-Polymerase-]inhibitor maintenance therapy [26-33]), on the other hand, the identification of as yet unaffected family members, where, with autosomal-dominant inheritance, $50 \%$ are transferred the pathogenic BRCA mutation. The clinically significant therapeutic benefit of maintenance therapy with PARP inhibitors was initially demonstrated in patients with relapsed high-grade serous/endometrioid ovarian cancer, and in this case especially where a BRCA1/2 mutation was present [27, $29,30]$. The latest study data provide evidence that this effect can also be achieved in the primary situation with PARP-inhibitor maintenance therapy $[26,28,31,32]$. 


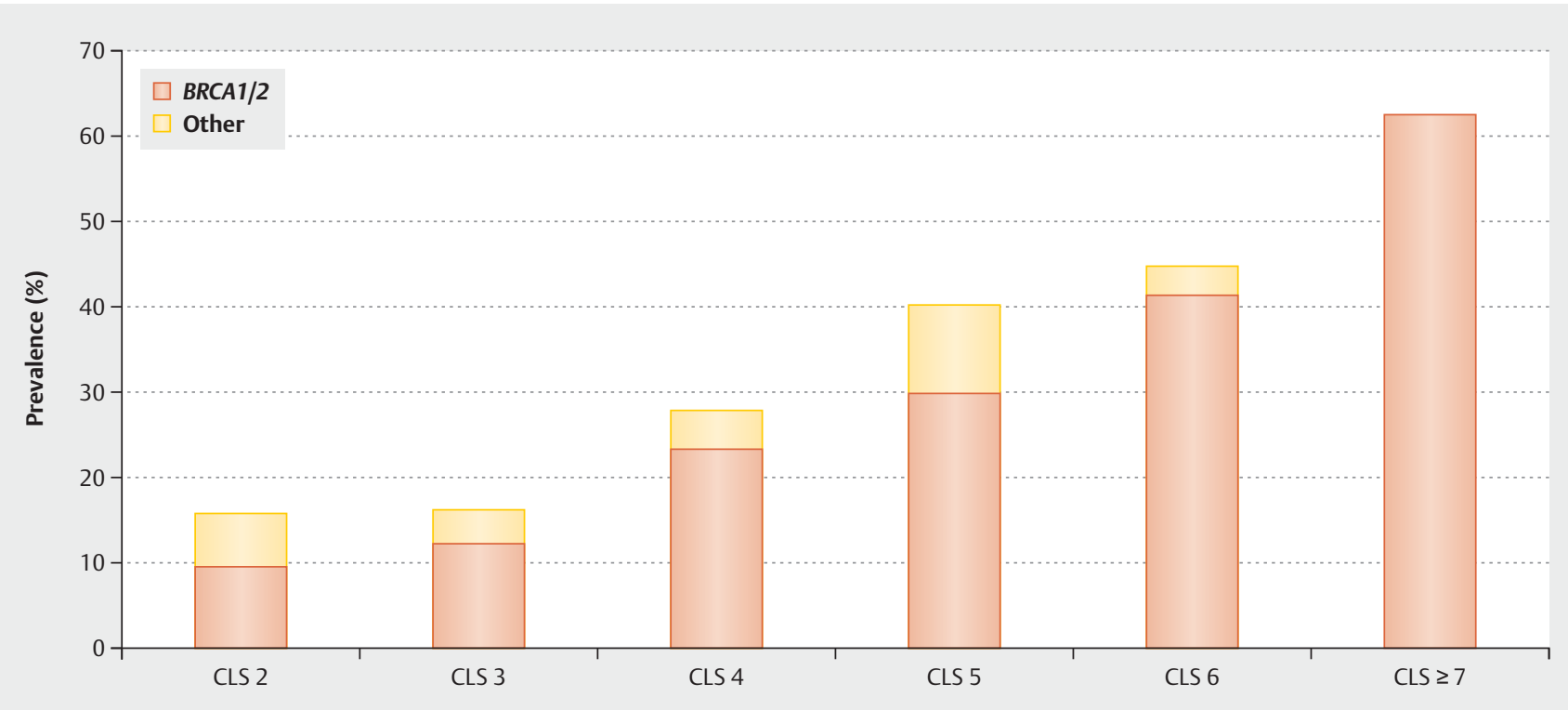

- Fig. 3 Prevalence of pathogenic mutations depending on the heritability checklist score (CLS) in the gene panel cohort ( $n=453)$.

Regardless of the success of the PARP inhibitors, the identification of healthy $B R C A 1 / 2$ mutation carriers in the family, through testing the patient, is of clinical significance. Support and counselling of risk gene carriers should be performed in specialised centres in line with the consensus recommendations of the German Consortium [34].

Compared to the normal population and depending on the affected gene, healthy women with a pathogenic BRCA1/2 mutation have a significantly increased risk of breast (up to $70 \%$ ) and/or ovarian cancer (up to $63 \%$ ) [5-13]. Prevalence of BRCA1/2 gene mutations in the normal population is low, at 1:300-500 [812 ], and is currently not yet rated as sufficient justification for unselected population analysis. Therefore, in the past, different riskassessment strategies were developed for the detection of risk groups with a substantially higher probability ( $\geq 10 \%)$ of $B R C A 1 / 2$ mutation [17,35-42]. All are based on a probability calculation for BRCA1/2 mutation being carried out for the affected person on the basis of personal/family history for breast/ovarian cancer and age at first diagnosis. In Germany, the German Consortium for Hereditary Breast and Ovarian Cancer established and validated inclusion criteria which have to be fulfilled before there is an indication for counselling and testing for a BRCA1/2 mutation. For easier, everyday use, a heritability checklist was drawn up [16], with the indication for genetic briefing/counselling and testing ( $\geq 3$ points) based on the total point value. Rhiem et al. were able to show that the checklist was used successfully in breast cancer patients, with a positive correlation between the score value and prevalence of a BRCA1/2 mutation [17].

This analysis based on the checklist has, to date, not been carried out for patients with ovarian cancer. According to the heritability checklist, patients with singular ovarian cancer receive 2 points, and, on the basis of this survey, are not a priori identified as index patients for genetic briefing/counselling and testing, since historic study data suggested a prevalence of less than $10 \%$ for BRCA1/2 mutation in this constellation [43]. The predictive value of the family history (for breast and ovarian cancer) with regard to the prevalence of a pathogenic BRCA1/2 mutation is undisputed. $19-81 \%$ of ovarian cancer patients with other relatives with breast and/or ovarian cancer in their family, carry a BRCA1/2 mutation $[12,20,44,45]$. Here, the prevalence correlates not only with the number of affected persons, but also with age at first diagnosis (the younger, the higher) and with the disease (higher prevalence with ovarian cancers). It is, however, known that a large proportion of ovarian cancer patients have no predisposition in the family history. In our collective, $41 \%$ of patients had no such predisposition. In the AGO-OVAR-TR1 study [20], the prevalence of gene mutation was analysed using the gene panel in 523 ovarian cancer patients with a first diagnosis or relapse. The prevalence for a pathogenic BRCA1/2 mutation was $21 \%$ in the overall cohort. In this study, $57 \%$ of patients had no positive family history, but the prevalence for a pathogenic mutation in this group was $11.4 \%$. In patients with a positive family history, the prevalence was $31.6 \%$. Specifically, this means that, in 33 (6.3\% of the overall cohort) patients with singular ovarian cancer, a pathogenic $B R C A$ mutation would not have been detected if the test criteria had been applied only according to the predisposing family history. In our collective, this rate was $4.4 \%(n=24)$, other workgroups report $6.5-9 \%[43,45]$. This means that around $1 / 3$ of $B R C A 1 / 2$ germline mutations are overlooked if testing is decided solely on the basis of a positive family history. Critical consideration should be given to the fact that information on the medical history of family members harbours a high potential for sources of error and therefore the robustness should be viewed as limited. Furthermore, in the case of adoption or a lack of contact within a family, a sufficient family history of malignancies cannot be obtained.

Recent study results, however, show that both an unselected population analysis [46] and in particular genetic analysis in EOC 
patients [47] and first degree relatives [48] are not only cost effective, but can also contribute to the lowering of hereditary EOC. Since there exists neither a sufficiently reliable drug prevention option nor an adequate early detection measure for ovarian cancer, only prophylactic, risk-reducing bilateral salpingo-oophorectomy for mutation carriers offers a reduction in the disease and mortality risk by around $80 \%[49,50]$.

Furthermore, the use of gene panel analyses demonstrates that other relevant pathogenic gene mutations can be detected regardless of the family disease situation [20]. In our collective, the rate of additional pathogenic mutation was $6.2 \%$. This aspect is of particular significance, since this again allowed detection of healthy mutation carriers in the family circle, whose risk of developing malignancies is correspondingly increased.

The weaker aspects of our work are based on the one hand on the retrospective nature of the evaluation, where a selection bias cannot be excluded. On the other hand, a gene result was available to us in only $45 \%$ of our entire patient collective. This is due to the fact that, according to the Genetic Diagnostics Act, the genetic counselling must be "non-directive" and therefore conducted on a voluntary basis for the patient. Furthermore, there is no predefined time window after the initial diagnosis for performing a genetic analysis. This fact, coupled with the requirements of the Genetic Diagnostics Act, means that actively inquiring about genetic findings from EOC patients, who received their surgical therapy at our centre and afterwards continue their treatment close to home, is not permitted. The strengths of our work merit highlighting:

1. The data represent an unselected cohort of EOC patients with a primary diagnosis in a large clinic collective and thus optimally reflect the clinical reality;

2. Enquiries on the family history are carried out in a structured manner using the heritability checklist;

3. The proportion of EOC patients with a gene panel analysis is very high and therefore reflects reliable data.

In summary, our work allowed us to confirm that the prevalence of a pathogenic BRCA1/2 mutation in patients with singular ovarian cancer in our collective is $23.3 \%$ and thus clearly above the required limit of $\geq 10 \%$, where genetic testing is indicated according to the criteria of the German Consortium for Hereditary Breast and Ovarian Cancer. Furthermore, we were able to demonstrate a positive correlation between the heritability checklist score and the prevalence of a pathogenic BRCA1/2 mutation. These data provide a crucial contribution to clinical healthcare research in Germany. Consistent with the recommendations of various national and international professional societies/guidelines, we therefore recommend genetic counselling and testing of patients with ovarian cancer regardless of their family history $[15,21,51$, 52] and argue in favour of clear identification of this indication in the heritability checklist used in Germany.

\section{Conflict of Interest}

BA (Consulting activities: Roche, Amgen, Tesaro; Advanced training/ conferences/lecture honoraria: Roche, AstraZeneca, Tesaro, Clovis, Amgen, Celgene, PharmaMar).

DT No conflicts of interest.

KR (Consulting activities: AstraZeneca, Pfizer, Tesaro; Advanced training/conferences/lecture honoraria: AstraZeneca, Pfizer, Tesaro; Immaterial conflicts of interest/affiliation with scientific schools: German Consortium for Hereditary Breast and Ovarian Cancer).

PH (Consulting activities: AstraZeneca, Roche, Sitio, Tesaro, Lilly, Clovis, MSD, Merck; Author activity/expert reviewer activity: AstraZeneca; Advanced training/conferences/lecture honoraria: AstraZeneca, Roche, Tesaro, Stryker, ZaiLab, MSD/Merck; Scientific activities: AstraZeneca, Roche DFG, EU, Genmab).

StS (Consulting activities: Clovis, Tesaro; Advanced training/ conferences/lecture honoraria: PharmaMar, Roche, Tesaro, Roche, AstraZeneca).

FH (Consulting activities: AstraZeneca, Tesaro, Clovis; Advanced training/conferences/lecture honoraria: AstraZeneca, Tesaro, Clovis, Roche, PharmaMar).

TB (Consulting activities: Tesaro; Advanced training/conferences/lecture honoraria: Roche, Amgen; Scientific activity: Amgen).

AT No conflicts of interest.

NP No conflicts of interest.

SE (Non-financial support: Tesaro).

HP No conflicts of interest.

RS (Consulting activities: AstraZeneca; Advanced training/conferences/ lecture honoraria: AstraZeneca; Scientific activities: AGO study group; Immaterial conflict of interest/affiliation with scientific schools: German Consortium for Hereditary Breast and Ovarian Cancer).

AdB (Consulting activities: AstraZeneca, Clovis, Tesaro, Roche, Genmab, BIOCAD, Pfizer, MSD; Advanced training/conferences/lecture honoraria: AstraZeneca, Clovis, Tesaro; Scientific activities: AstraZeneca, Tesaro, Roche, Genmab, BIOCAD).

\section{References}

[1] 2019. Online: https://www.krebsdaten.de/Krebs/DE/Content/ Publikationen/Krebs_in_Deutschland/kid_2019/krebs_in_deutschland_ 2019.pdf;jsessionid=2570AF7C1C6BFEEEE3203FF14DD227F3.1_ cid290?_blob=publicationFile

[2] Torre LA, Trabert B, DeSantis CE et al. Ovarian cancer statistics, 2018. CA Cancer J Clin 2018; 68: 284-296. doi:10.3322/caac.21456

[3] Mavaddat N, Peock S, Frost D et al. Cancer risks for BRCA1 and BRCA2 mutation carriers: results from prospective analysis of EMBRACE. J Natl Cancer Inst 2013; 105: 812-822. doi:10.1093/jnci/djt095

[4] Antoniou A, Pharoah PD, Narod S et al. Average risks of breast and ovarian cancer associated with BRCA1 or BRCA2 mutations detected in case Series unselected for family history: a combined analysis of 22 studies. Am J Hum Genet 2003; 72: 1117-1130. doi:10.1086/375033

[5] King MC, Marks JH, Mandell JB et al. Breast and ovarian cancer risks due to inherited mutations in BRCA1 and BRCA2. Science 2003; 302: 643646. doi:10.1126/science. 1088759

[6] Antoniou AC, Cunningham AP, Peto J et al. The BOADICEA model of genetic susceptibility to breast and ovarian cancers: updates and extensions. Br J Cancer 2008; 98: 1457-1466. doi:10.1038/sj.bjc.6604305

[7] Mavaddat N, Peock S, Frost D et al. Cancer risks for BRCA1 and BRCA2 mutation carriers: results from prospective analysis of EMBRACE. J Natl Cancer Inst 2013; 105: 812-822. doi:10.1093/jnci/djt095

[8] Antoniou AC, Gayther SA, Stratton JF et al. Risk models for familial ovarian and breast cancer. Genet Epidemiol 2000; 18: 173-190. doi:10.1002/(SICI)1098-2272(200002)18:2<173::AID-GEPI6>3.0.CO;2-R 
[9] [Anonym]. Prevalence and penetrance of BRCA1 and BRCA2 mutations in a population-based series of breast cancer cases. Anglian Breast Cancer Study Group. Br J Cancer 2000; 83: 1301-1308. doi:10.1054/ bjoc.2000.1407

[10] Antoniou AC, Pharoah PD, McMullan G et al. A comprehensive model for familial breast cancer incorporating BRCA1, BRCA2 and other genes. $\mathrm{Br}$ J Cancer 2002; 86: 76-83. doi:10.1038/sj.bjc.6600008

[11] Peto J, Collins N, Barfoot R et al. Prevalence of BRCA1 and BRCA2 gene mutations in patients with early-onset breast cancer. J Natl Cancer Inst 1999; 91: 943-949. doi:10.1093/jnci/91.11.943

[12] Kast K, Rhiem K, Wappenschmidt B et al. Prevalence of BRCA1/2 germline mutations in 21401 families with breast and ovarian cancer. J Med Genet 2016; 53: 465-471. doi:10.1136/jmedgenet-2015-103672

[13] Kuchenbaecker KB, Hopper JL, Barnes DR et al. Risks of Breast, Ovarian, and Contralateral Breast Cancer for BRCA1 and BRCA2 Mutation Carriers. JAMA 2017; 317: 2402-2416. doi:10.1001/jama.2017.7112

[14] 2019. Online: https://www.konsortium-familiaerer-brustkrebs.de/ informationen/gentest-einschlusskriterien/

[15] Online: https://www.nccn.org/professionals/physician_gls/pdf/genetics _screening.pdf

[16] 2019. Online: https://www.konsortium-familiaerer-brustkrebs.de/ medien/user_upload/Checkliste_10_05_2019.pdf

[17] Rhiem K, Bucker-Nott HJ, Hellmich M et al. Benchmarking of a checklist for the identification of familial risk for breast and ovarian cancers in a prospective cohort. Breast J 2019; 25: 455-460. doi:10.1111/tbj.13257

[18] 2019. Online: https://www.krebsgesellschaft.de/zertdokumente.html

[19] 2019. Online: https://www.onkozert.de/organ/gyn/

[20] Harter P, Hauke J, Heitz F et al. Prevalence of deleterious germline variants in risk genes including BRCA1/2 in consecutive ovarian cancer patients (AGO-TR-1). PLoS One 2017; 12: e0186043. doi:10.1371/journal. pone. 0186043

[21] S3 Leitlinie Maligne Ovarialatumore. Online: https://www. leitlinienprogramm-onkologie.de/fileadmin/user_upload/Downloads/ Leitlinien/Ovarialkarzinom/Version_3_2018_/LL_Ovarialkarzinom_ Langversion_3.0.pdf

[22] Hauke J, Horvath J, Gross E et al. Gene panel testing of 5589 BRCA1/2negative index patients with breast cancer in a routine diagnostic setting: results of the German Consortium for Hereditary Breast and Ovarian Cancer. Cancer Med 2018; 7: 1349-1358. doi:10.1002/cam4.1376

[23] Bolton KL, Chenevix-Trench G, Goh C et al. Association between BRCA1 and BRCA2 mutations and survival in women with invasive epithelial ovarian cancer. JAMA 2012; 307: 382-390. doi:10.1001/jama.2012.20

[24] Norquist BM, Brady MF, Harrell Ml et al. Mutations in Homologous Recombination Genes and Outcomes in Ovarian Carcinoma Patients in GOG 218: An NRG Oncology/Gynecologic Oncology Group Study. Clin Cancer Res 2018; 24: 777-783. doi:10.1158/1078-0432.CCR-17-1327

[25] Li A, Xie R, Zhi Q et al. BRCA germline mutations in an unselected nationwide cohort of Chinese patients with ovarian cancer and healthy controls. Gynecol Oncol 2018; 151: 145-152. doi:10.1016/j.ygyno. 2018.07.024

[26] Coleman RL, Fleming GF, Brady MF et al. Veliparib with First-Line Chemotherapy and as Maintenance Therapy in Ovarian Cancer. N Engl J Med 2019; 381: 2403-2415. doi:10.1056/NEJMoa1909707

[27] Coleman RL, Oza AM, Lorusso D et al. Rucaparib maintenance treatment for recurrent ovarian carcinoma after response to platinum therapy (ARIEL3): a randomised, double-blind, placebo-controlled, phase 3 trial. Lancet 2017; 390: 1949-1961. doi:10.1016/S0140-6736(17)32440-6

[28] Gonzalez-Martin A, Pothuri B, Vergote I et al. Niraparib in Patients with Newly Diagnosed Advanced Ovarian Cancer. N Engl J Med 2019; 381: 2391-2402. doi:10.1056/NEJMoa1910962
[29] Ledermann J, Harter P, Gourley C et al. Olaparib maintenance therapy in patients with platinum-sensitive relapsed serous ovarian cancer: a preplanned retrospective analysis of outcomes by BRCA status in a randomised phase 2 trial. Lancet Oncol 2014; 15: 852-861. doi:10.1016/S14702045(14)70228-1

[30] Mirza MR, Monk B], Herrstedt J et al. Niraparib Maintenance Therapy in Platinum-Sensitive, Recurrent Ovarian Cancer. N Engl J Med 2016; 375: 2154-2164. doi:10.1056/NEJMoa 1611310

[31] Moore K, Colombo N, Scambia G et al. Maintenance Olaparib in Patients with Newly Diagnosed Advanced Ovarian Cancer. N Engl J Med 2018; 379: 2495-2505. doi:10.1056/NEJMoa1810858

[32] Ray-Coquard I, Pautier P, Pignata S et al. Olaparib plus Bevacizumab as First-Line Maintenance in Ovarian Cancer. N Engl J Med 2019; 381: 2416-2428. doi:10.1056/NEJMoa1911361

[33] du Bois A, Reuss A, Pujade-Lauraine E et al. Role of surgical outcome as prognostic factor in advanced epithelial ovarian cancer: a combined exploratory analysis of 3 prospectively randomized phase 3 multicenter trials: by the Arbeitsgemeinschaft Gynaekologische Onkologie Studiengruppe Ovarialkarzinom (AGO-OVAR) and the Groupe d'Investigateurs Nationaux Pour les Etudes des Cancers de l'Ovaire (GINECO). Cancer 2009; 115: 1234-1244. doi:10.1002/cncr.24149

[34] Online: https://www.konsortium-familiaerer-brustkrebs.de/ konsensusempfehlung/KzUmEdM

[35] Antoniou AC, Hardy R, Walker L et al. Predicting the likelihood of carrying a BRCA1 or BRCA2 mutation: validation of BOADICEA, BRCAPRO, IBIS, Myriad and the Manchester scoring system using data from UK genetics clinics. J Med Genet 2008; 45: 425-431. doi:10.1136/jmg. 2007.056556

[36] Ashton-Prolla P, Giacomazzi J, Schmidt AV et al. Development and validation of a simple questionnaire for the identification of hereditary breast cancer in primary care. BMC Cancer 2009; 9: 283. doi:10.1186/ 1471-2407-9-283

[37] Barcenas CH, Hosain GM, Arun B et al. Assessing BRCA carrier probabilities in extended families. J Clin Oncol 2006; 24: 354-360. doi:10.1200/ JCO.2005.02.2368

[38] Evans DG, Eccles DM, Rahman $\mathrm{N}$ et al. A new scoring system for the chances of identifying a BRCA1/2 mutation outperforms existing models including BRCAPRO. J Med Genet 2004; 41: 474-480. doi:10.1136/ jmg.2003.017996

[39] Fischer C, Kuchenbacker K, Engel C et al. Evaluating the performance of the breast cancer genetic risk models BOADICEA, IBIS, BRCAPRO and Claus for predicting BRCA1/2 mutation carrier probabilities: a study based on 7352 families from the German Hereditary Breast and Ovarian Cancer Consortium. J Med Genet 2013; 50: 360-367. doi:10.1136/ jmedgenet-2012-101415

[40] Hoskins KF, Zwaagstra A, Ranz M. Validation of a tool for identifying women at high risk for hereditary breast cancer in population-based screening. Cancer 2006; 107: 1769-1776. doi:10.1002/cncr.22202

[41] Parmigiani G, Chen S, Iversen ES jr. et al. Validity of models for predicting BRCA1 and BRCA2 mutations. Ann Intern Med 2007; 147: 441-450. doi:10.7326/0003-4819-147-7-200710020-00002

[42] Teller P, Hoskins KF, Zwaagstra A et al. Validation of the pedigree assessment tool (PAT) in families with BRCA1 and BRCA2 mutations. Ann Surg Oncol 2010; 17: 240-246. doi:10.1245/s10434-009-0697-9

[43] Risch HA, McLaughlin JR, Cole DE et al. Prevalence and penetrance of germline BRCA1 and BRCA2 mutations in a population series of 649 women with ovarian cancer. Am J Hum Genet 2001; 68: 700-710. doi: $10.1086 / 318787$

[44] Ramus S], Harrington PA, Pye $C$ et al. Contribution of BRCA1 and BRCA2 mutations to inherited ovarian cancer. Hum Mutat 2007; 28: 12071215. doi:10.1002/humu.20599 
[45] Singer CF, Tan YY, Muhr D et al. Association between family history, mutation locations, and prevalence of BRCA1 or 2 mutations in ovarian cancer patients. Cancer Med 2019; 8: 1875-1881. doi:10.1002/cam4.2000

[46] Manchanda R, Patel S, Gordeev VS et al. Cost-effectiveness of Population-Based BRCA1, BRCA2, RAD51C, RAD51D, BRIP1, PALB2 Mutation Testing in Unselected General Population Women. J Natl Cancer Inst 2018; 110: 714-725. doi:10.1093/jnci/djx265

[47] Eccleston A, Bentley A, Dyer M et al. A Cost-Effectiveness Evaluation of Germline BRCA1 and BRCA2 Testing in UK Women with Ovarian Cancer. Value Health 2017; 20: 567-576. doi:10.1016/j.jval.2017.01.004

[48] Kwon JS, Tinker AV, Hanley GE et al. BRCA mutation testing for first-degree relatives of women with high-grade serous ovarian cancer. Gynecol Oncol 2019; 152: 459-464. doi:10.1016/j.ygyno.2018.10.014
[49] Domchek SM, Friebel TM, Singer CF et al. Association of risk-reducing surgery in BRCA1 or BRCA2 mutation carriers with cancer risk and mortality. JAMA 2010; 304: 967-975. doi:10.1001/jama.2010.1237

[50] Finch AP, Lubinski J, Moller P et al. Impact of oophorectomy on cancer incidence and mortality in women with a BRCA1 or BRCA2 mutation. J Clin Oncol 2014; 32: 1547-1553. doi:10.1200/JCO.2013.53.2820

[51] Colombo N, Sessa C, du Bois A et al. ESMO-ESGO consensus conference recommendations on ovarian cancer: pathology and molecular biology, early and advanced stages, borderline tumours and recurrent diseasedagger. Ann Oncol 2019; 30: 672-705. doi:10.1093/annonc/ $\mathrm{mdz} 062$

[52] Domchek SM, Robson ME. Update on Genetic Testing in Gynecologic Cancer. J Clin Oncol 2019; 37: 2501-2509. doi:10.1200/JCO.19.00363 